\title{
PENGEMBANGAN BAHAN PEMBELAJARAN MATEMATIKA BERBASIS PROBLEM POSING KELAS VII
}

\section{( DEVELOPMENT OF MATHEMATICS LEARNING MATERIALS BASED ON CLASS PROBLEM CLASS VII)}

\author{
Shandra Amalia ${ }^{1}$, Yogi Wiratomo ${ }^{2}$ \\ ${ }^{1}$ Universitas Indraprasta PGRI Jakarta, shandraamalia82@gmail.com \\ ${ }^{2}$ Universitas Indraprasta PGRI Jakarta, ywiratomo@gmail.com
}

\begin{abstract}
Abstrak
Tujuan dari penelitian ini adalah untuk menghasilkan suatu bahan ajar berbentuk buku pembelajaran yang efektif untuk memfasilitasi proses pembelajaran matematika peserta didik kelas VII SMP Semester 2. Buku matematika ini dibuat berdasarkan hasil analisis kebutuhan terhadap kompetensi matematika yang seharusnya dimiliki peserta didik kelas VII SMP. Alat pengambilan data berupa angket pertanyaan untuk guru sekolah SMP kelas VII. Proses penelitian diadaptasi dari model pengembangan instruksional (MPI) M. Atwi Suparman yang terdiri dari beberapa langkah, yaitu: (1) mengindentifikasi kebutuhan dan menulis tujuan instruksional, (2) melakukan analisis instruksional, (3) mengidentifikasi perilaku dan karakteristik awal peserta didik, (4) menulis tujuan instruksional khusus, (5) menyusun alat penilaian hasil belajar, (6) menyusun strategi instruksional, (7) mengembangkan bahan instruksional, (8) melakukan evaluasi formatif. Temuan penelitian yaitu dihasilkan bahan ajar berbentuk buku pembelajaran untuk peserta didik kelas VII SMP pada semester 2.
\end{abstract}

Kata kunci: Buku Matematika, Problem Posing.

\section{Abstract}

The goal of this study was to produce an effective study book, to facilitate the seventh grade teaching process of junior high school students. The math book was based on the necessity of analysis of the supposed seventh grade school. It's question basket data retrieval for a junior high school teacher. The process of research was adapted from the instructional development model M. Atwi Suparman of several steps, which is: (1) identifying needs and writing instructional purposes, (2) conducting instructional analysis, (3) identifying early behavior and characteristics of learners, (4) writing specific instructional purposes, (5) learning assessment, (6) strategizing instructions, (7) developing instructional material, and (8) doing formative evaluation. The findings of this study were produced in the form of a learning book for seventh grade educators second semester.

Keywords: Math Books, Problem Posing. 


\section{PENDAHULUAN}

Salah satu faktor yang berperan dalam peningkatan pembelajaran matematika tidak lain adalah sumber belajar. Sumber belajar dapat dari buku, majalah, brosur, video, internet, dan lain-lain. Buku teks merupakan salah satu bahan ajar yang digunakan dalam pembelajaran matematika. Pentingnya buku teks sebagai penunjang dalam pembelajaran menyebabkan jenis buku yang beredar beragam. Permasalahan yang dihadapi, yaitu bagaimana memilih buku teks yang beragam tersebut sebagai pendamping dalam pelajaran (Sari, 2016).

Sebagai buku pendidikan, buku teks memegang peranan penting dalam pembelajaran. Dengan buku teks, program pembelajaran dapat dilaksanakan secara lebih teratur, sebab guru sebagai pelaksana pendidikan akan memperoleh pedoman materi yang jelas. Buku Sekolah Elektronik (BSE)- matematika kelas VII terdapat beberapa sub yang tidak menggunakan masalah sehari-hari dalam pengenaan materinya, serta masih ada materi yang tidak dijelaskan secara konstektual (Fitriana, 2016) Kekurangan tersebut membuat siswa sedikit lebih lama dalam menangkap apa yang dimaksud dibuku tersebut. Guru pun tidak hanya terpaku pada buku BSE saja, ada buku-buku lain yang menjadi pegangan guru dalam mengajar.

Buku teks yang baik merupakan buku teks yang mampu menyajikan materi matematika sesuai dengan realita, mampu merangsang, mengorganisasi siswa untuk belajar dan mampu memberikan penataan serta penekanan materi pada siswa memalui pelatihan soal yang diberikan. Sesuai dengan tujuan pembelajaran matematika untuk tinggat SMP dari Badan Standar Nasional Pendidikan (BSNP), yaitu agar siswa mempunyai kemampuan 1) memahami konsep matematika, menjelaskan keterkaitan antar konsep dan mengaplikasikan konsep atau algoritma, secara luwes, akurat, efisien, dan tepat dalam pemecahan masalah, 2) menggunakan penalaran pada pola dan sifat, melakukan manipulasi matematika dalam membuat generalisasi, menyusun bukti atau menjelaskan gagasan dan pernyataan matematika, 3) memecahkan masalah yang meliputi kemampuan memahami masalah, merancang model matematika, menyelesaikan model dan menafsirkan solusi yang diperoleh, dan 4) mengomunikasikan gagasan dengan simbol, tabel, diagram, atau media lain untuk memperjelas keadaan atau masalah, serta 5) memiliki sikap menghargai kegunaan matematika dalam kehidupan, yaitu memiliki rasa ingin tahu, perhatian, minat dalam mempelajari matematika, sikap ulet dan percaya diri dalam pemecahan masalah (Sundayana, 2016). Berdasarkan tujuan pembelajaran matematika di atas, bahwa kemampuan pemecahan masalah matematis dan sikap ulet serta percaya diri dalam pemecahan masalah merupakan kemampuan yang sangat penting dimiliki siswa.

Upaya yang dapat dilakukan guru untuk meningkatkan kemampuan pemecahan masalah dan kemandirian belajar dengan memiliki metode yang tepat dalam pengajarannya. Salah satu yang dapat mencangkup hal tersebut adalah Problem Posing. Pendekatan ini memberikan kesempatan kepada siswa untuk menyampaikan (merumuskan) suatu soal matematika yang lebih sederhana dalam rangka menyelesaikan soal yang sulit ataupun kompleks (Haji, 2014). Pendekatan semacam ini dapat menumbuhkan kreatifitas siswa, sehingga diharapkan hasil pembelajarannya menjadi lebih baik.

Problem Posing dapat membantu siswa dalam mencari topik baru dan menyediakan pemahaman yang lebih mendalam. Selain itu Problem Posing juga 
dapat menciptakan ide-ide baru yang berasal dari setiap topik yang diberikan. Pendekatan dengan Problem Posing mendorong murid membuat soalnya sendiri yang tidak jauh berbeda dengan soal yang diberikan oleh guru. Prinsip dari pendekatan pembelajaran dengan Problem Posing adalah suatu pendekatan pembelajaran yang mewajibkan siswa untuk mengajukan soal sendiri melalui belajar (berlatih soal) secara mandiri.

\section{KAJIAN TEORI}

Pengembangan menurut Undung-Undang Republik Indonesia Nomor 18 Tahun 2002 adalah kegiatan ilmu pengetahuan dan teknologi yang bertujuan memanfaatkan kaidah dan teori ilmu pengetahuan yang telah terbukti kebenarannya untuk meningkatkan fungsi, manfaat, aplikasi ilmu pengetahuan dan teknologi yang telah ada, atau menghasilkan teknologi baru. Pengembangan dapat juga diartikan sebagai suatu proses yang dipakai untuk mengembangkan dan memvalidasi produk pendidikan. Proses pengembangan terdiri dari kajian temuan produk yang akan dikembangkan, mengembangkan produk berdasarkan temuan tersebut, selanjutnya dilakukan uji coba lapangan sesuai dengan latar belakang dimana produk itu akan dipakai, dan melakukan revisi terhadap hasil uji lapangan (Setyosari, 2013).

Buku adalah buah pikiran yang berisi ilmu pengetahuan hasil analisis terhadap kurikulum secara tertulis. Buku disusun menggunakan bahasa sedehana, menarik, dan dilengkapi gambar serta daftar pustaka (Kurniasih, 2014). Buku juga sebagai bahan ajar yang dapat membantu dalam proses pembelajaran baik pendidik maupun peserta didik. Quest (Tarigan, 2009) mengatakan bahwa buku adalah rekaman pikiran rasial yang disusun untuk maksud dan tujuan instruksional.

Sejalan dengan pendapat sebelumnya buku juga merupakan sarana belajar yang biasa digunakan di sekolah dan di perguruan tinggi untuk menunjang suatu program pengajaran (Buckingham dalam Tarigan, 2009). Buku merupakan sarana belajar yang dapat digunakan di sekolah maupun di perguruan tinggi sekalipun.

Buku pembelajaran terdiri dari beberapa jenis. Salah satunya buku yang sering digunakan di sekolah disebut juga buku teks pelajaran. Buku teks pelajaran berisi ilmu pengetahuan, yang diturunkan dari kompetensi dasar yang tertuang dalam kurikulum, dimana buku tersebut digunakan oleh peserta didik (Prastowo, 2011).

"Problem posing adalah salah satu metode dalam mempelajari matematika yang disarankan oleh NCTM (Nasional Cauncil of Mathematics). Hal tersebut dikemukakan oleh NCTM karena problem posing merupakan "The heart of doing mathematicsi", inti dari matematika" (Hidayah \& Leonard, 2013). NCTM merekomendasikan agar siswa diberi kesempatan untuk mengalami membuat soal sendiri (problem posing).

Problem posing memunyai beberapa arti yaitu, (1) perumusan soal sederhana atau perumusan kembali soal yang ada dengan beberapa perubahan agar lebih sederhana dan dapat dikuasai; (2) perumusan soal yang berkaitan dengan syarat-syarat pada soal yang telah diselesaikan dalam rangka mencari penyelesaian masalah; (3) perumusan soal dari informasi atau situasi yang tersedia, baik dilakukan sebelum, ketika, atau setelah pemecahan masalah (Hobri, 2009). 
Tahap-tahapan problem posing dibagi menjadi tiga bagian yaitu: (1) PreSolution. Sebelum menyelesaikan masalah, dimana beberapa masalah dihasilkan secara teliti dari stimulasi yang disajikan seperti sebuah gambar, kisah atau cerita, diagram, paparan dan sebagainya; (2) During (within-solution). Selama penyelesaian masalah ketika siswa sengaja merubah suatu hasil dan kondisi dari permasalahan; dan (3) After Problem Posing (post-solution). Setelah penyelesaian masalah, pengalaman dari konteks penyelesaian masalah diterapkan pada situasi yang baru (Thobroni \& Mustofa, 2012).

Informasi atau situasi problem posing dapat berupa gambar, benda manipulative, permainan, teorema atau konsep, alat peraga, masalah, atau penyelesaian dari suatu masalah. Selain itu jenis informasi dalam problem posing ada dua, yaitu;

1) Informasi bergambar

Informasi bergambar ini dibedakan menjadi dua yaitu, informasi bergambar yang disertai keterangan gambar dan informasi bergambar yang tidak disertai gambar, kecuali berupa kata sebagai penjelasan gambar.

2) Informasi tak bergambar

Informasi tak bergambar atau informasi yang berupa kalimat dibedakan menjadi tiga yaitu, informasi yang berupa kalimat pernyataan, informasi berupa kalimat pertanyaan saja, dan informasi berupa kalimat pertanyaan dan pernyataan.).

\section{METODE PENELITIAN}

Jenis penelitian yang digunakan adalah penelitian pengambangan instruksional dengan model MPI. Produk yang dikembangkan adalah bahan instruksional pada pembelajaran matematika SMP kelas VII untuk memfasilitasi peserta didik dalam pemecahan masalah pelajaran matematis. Pendekatan penelitian dan pengembangan merupakan suatu cara proses yang digunakan untuk mengembangkan dan menvalidasi produk-produk penelitian. Penelitian dan pengembangan berbeda dengan penelitian pengambangan (research development). Tujuan dari penelitian dan pengembangan adalah untuk menjambani kesenjangan antara suatu yang terjadi dalam penelitian pendidikan dengan praktik pendidikan dan menghasilkan produk penelitian yang digunakan untuk mengembangkan mutu pendidikan dan pembelajaran secara efektif. Teknik pengambilan data menggunakan sebaran angket untuk guru SMP kelas VII. Penelitian dilaksanakan di bulan Maret - Agustus 2019 pada SMP diwilayah Kramat Jati, Jakarta Timur.

Pengembangan desain pembelajaran yang digunakan dalam penelitian ini mengacu pada Model Pengembangan Instruksional (MPI) terdiri dari tiga tahap (Suparman, 2014), yaitu: Identifikasi, tahap pengembangan, evaluasi dan revisi dan melaksanakan evaluasi formatif. 
Alur proses MPI adalah seperti gambar berikut :

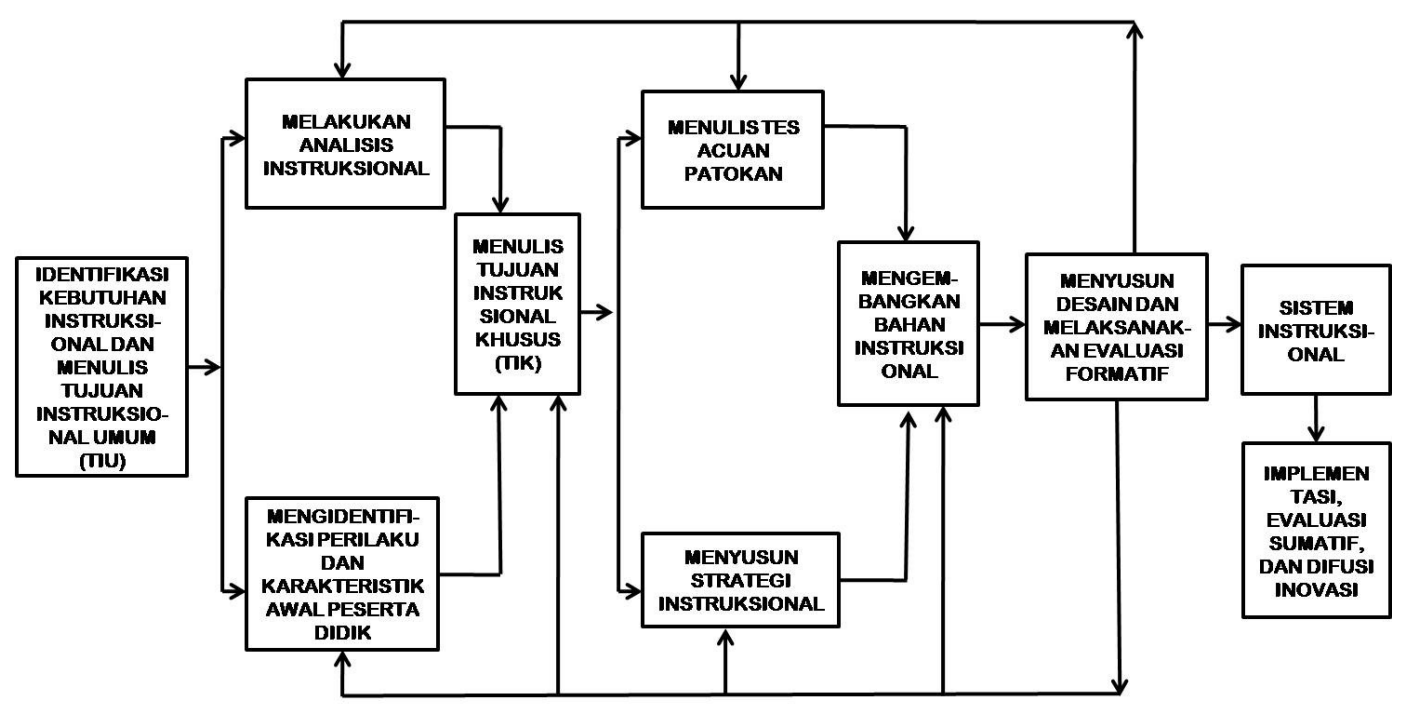

Gambar 1. Model Desain Instruksional Modern

Sumber: (Suparman, 2014)

Penelitian ini hanya sampai tahap evaluasi formatif, yaitu dengan menganalisis hasil uji formatif dari pakar. Indikator yang digunakan dalam pengembangan bahan pembelajaran ini adalah dengan pelaksanaan revisi setelah tahapan uji formatif

\section{HASIL DAN PEMBAHASAN}

Hasil penelitian pengembangan ini adalah tersusunnya Bahan Instruksional Matematika dengan menambah nilai-nilai problem posing ke dalam pembahasan materi sesuai dengan Tujuan Instruksional Umum (TIU) pada kurikulum 2013. Produk bahan Instruksional ini memuat materi yang tercangkup dalam standar kompetensi untuk memahami materi kelas VII SMP pada peserta didik, serta untuk melatih peserta didik dapat membuat soal sendiri sehingga paham dengan berbagai macam soal yang akan diberikan. Bahan Intruksional ini berisi materi perbandingan, aritmatika sosial, garis dan sudut, segi empat, segitiga, dan penyajian data.

Setiap pembuka materi ditunjang dengan ikon owl (burung hantu) yang melambangkan kebijaksanaan dan keteladanan. Makna owl sendiri adalah sosok yang banyak melihat, mendengar, sedikit bicara, dan banyak bertindak. Bahan intruksional ini berbasis problem posing, sehingga dimasukan bagaiman cara membuat soal dengan tiga cara, yaitu; (1) Pre Solution Posing (membuat soal dari pernyataan yang diberikan), (2) Within Solution Posing (membuat soal dengan memecah soal tunggal menjadi sub-sub pertanyaan releven dengan soal yang diberikan), dan (3) Post Solution Posing (membuat soal baru yang masih berkaitan dengan soal yang diberikan). Sebelum memberikan contoh Problem Posing, diberikan soal dengan penyelesaian supaya memahami terlebih dahulu materi yang diajarkan. Setelah pemberian soal dengan penyelesaian, selanjutnya diberikan contoh cara membuat soal dengan Problem Posing yang dilakukan 
dengan tiga cara, serta diberikan latihan soal dengan atau tanpa Problem Posing. Sebelum menyusun bahan instrumen pembelajaran terdapat beberapa proses yang dilalui seperti menganalisis kebutuhan instruksional, menentukan tujuan instruksional, melakukan analisis instruksional, mengidentifkasi perilaku dan karakteristik peserta didik, menentukan Tujuan Instruksional Khusus (TIK), menyusun alat hasil belajar, menyusun strategi instruksional sehingga mengembangkan bahan instruksional. Berikut penjabaran proses pengembangan bahan instruksional.

\section{Analisis Kebutuhan Instruksional}

Analisis kebutuhan didapat dari hasil wawancara beberapa guru SMP di Jakarta Timur dengan hasil sebagai berikut :

Tabel 1. Identitas Kebutuhan untuk Menentukan Tujuan Instruksional

\begin{tabular}{|c|c|c|c|}
\hline $\begin{array}{l}\text { Karakteristik } \\
\text { umum anak kelas } \\
7 \text { SMP }\end{array}$ & $\begin{array}{l}\text { Sikap/perilaku } \\
\text { anak kelas } 7 \\
\text { SMP saat } \\
\text { menerima } \\
\text { pelajaran } \\
\text { matematika }\end{array}$ & $\begin{array}{c}\text { Kompetensi yang harus } \\
\text { dimiliki oleh siswa kelas } 7 \\
\text { SMP }\end{array}$ & Sumber \\
\hline $\begin{array}{l}\text { 1. Mulai } \\
\text { memperlihatka } \\
\text { n kreativitasnya } \\
\text { 2. Harus mulai } \\
\text { bertanggung } \\
\text { jawab } \\
\text { 3. Cepat merasa } \\
\text { bosan }\end{array}$ & $\begin{array}{l}\text { Respon peserta } \\
\text { didik baik. } \\
\text { Apabila diberi } \\
\text { tugas mereka } \\
\text { langsung } \\
\text { mengerjakan } \\
\text { dan bertanya } \\
\text { jika ada } \\
\text { kendala dalam } \\
\text { mengerjakan } \\
\text { tugas }\end{array}$ & $\begin{array}{l}\text { - } \text { Mampu memahami } \\
\text { konsep matematika dasar } \\
\text { - } \text { Siswa mampu } \\
\text { menyelesaikan tugas } \\
\text { yang diberikan guru } \\
\text { - } \\
\text { Siswa berani } \\
\text { mempresentasikan/bicara } \\
\text { di depan kelas yang } \\
\text { berkaitan dengan materi } \\
\text { yang dipelajari }\end{array}$ & $\begin{array}{l}\text { (Wawancara } \\
\text { beberapa } \\
\text { guru kelas } \\
\text { VII SMP di } \\
\text { Jakarta } \\
\text { Timur) } \\
\text { Pada: } \\
15 \text { Maret } \\
2019\end{array}$ \\
\hline
\end{tabular}

\section{Menulis Tujuan Instruksional Umum (TIU)}

Perumusan TIU dapat disusun dengan melihat dan memperhatikan kompetensi apa saja yang diperlukan oleh siswa kelas VII SMP. Rumusan TIU adalah sebagai berikut:

"Melalui pendekatan Problem Posing untuk siswa SMP kelas VII akan membutuhkan kegiatan-kegiatan yang melibatkan siswa dalam kegiatan pembelajaran secara aktif sehingga dapat menambah pengetahuan, pemahaman, dan pengalaman siswa. Pendekatan yang digunakan dalam mengembangkan bahan ajar ini adalah pendekatan Problem Posing dengan tujuan agar siswa dapat terlibat secara aktif, kreatif dan terampil dalam memecahkan masalah-masalah matematika dan dapat membuat soal sendiri”.

\section{Melakukan Analisis Instruksional}

Dalam melakukan analisis instruksional, maka disusun uraian peta kopetensi yang ingin dicapai dengan uraian peta kompetensi sebagai berikut :

1) Dapat menjelaskan pengertian perbandingan, 
2) Dapat memahami skala,

3) Menghitung faktor perbesaran atau pengecilan gambar berskala,

4) Dapat membedakan perbandingan senilai dan berbalik nilai,

5) Dapat membedakan nilai keseluruhan, nilai per unit, dan nilai sebagian,

6) Dapat memahami harga pembelian, harga penjualan, untung dan rugi,

7) Menghitung presentase untung dan rugi,

8) Dapat membedakan rabat, bruto, neto, dan tara,

9) Menghitung bunga tunggal dan pajak,

10) Memahami kedudukan dua garis dan panjang ruas garis

11) Dapat memahami hubungan antarsudut,

12) Dapat melukis sudut,

13) Membedakan jenis sudut,

14) Dapat menjelaskan pengertian dan jenis segi empat,

15) Mampu menjelaskan sifat-sifat segi empat,

16) Menghitung keliling dan luas segi empat,

17) Memahami pengertian segitiga,

18) Dapat melukis segitiga,

19) Menjelaskan sifat-sifat segitiga,

20) Mampu menghitung keliling dan luas segitiga,

21) Mampu memahami pengumpulan data,

22) Mampu membedakan bentuk penyajian data,

23) Dapat memahami diagram (piktrogram, diagram batang, diagram garis, dan diagram lingkaran),

24) Dapat membedakan data tunggal dan data berkelompok.

\section{Membuat Peta Kompetensi}

Uraian peta kompetensi di atas, tergambarkan kompetensi-kompetensi yang ingin dan harus dicapai oleh peserta didik SMP kelas VII dalam sebuah bagan yang tersusun dalam "Peta Kompetensi". Peta kompetensi yang dimaksud sebagai berikut:

Jika diberikan soal latihan matematika SMP kelas VII, maka peserta didik diharapkan mampu memahami dan mengerjakan dengan baik, dalam penyelesaian soal-soal latihan maupun dalam pemecahan masalah berbentuk soal cerita dengan sendiri, cepat, dan minimal benar $80 \%$ serta meningkatkan prilaku disiplin, jujur, bersyukur, dan tidak mudah putus asa.

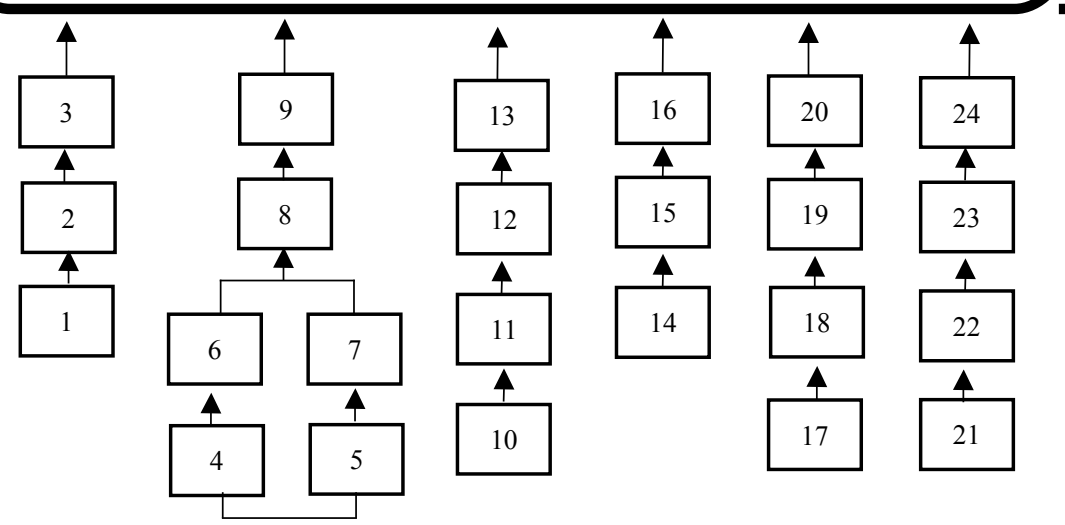




\section{Identifikasi Perilaku Peserta Didik SMP Kelas Tujuh}

Gambar 2. Peta Kompetensi SMP Kelas VII

Perilaku dan karakteristik yang ditunjukkan oleh peserta didik kelas 7 SMP antara lain sebagai berikut.

1) Kecenderungan minat dan pilihan karir relatif sudah lebih jelas

2) Senang membandingkan kaedah-kaedah, nilai-nilai etika atau norma dengan kenyataan yang terjadi dalam kehidupan orang dewasa

3) Mulai mengembangkan standar dan harapan terhadap perilaku diri sendiri yang sesuai dengan dunia sosial

4) Kecenderungan ambivalensi, antara keinginan untuk bebas dari dominasi dengan keinginan bergaul, serta ingin untuk bebas dari dominasi kebutuhan bimbingan dan bantuan dari orang tua.

\section{Tujuan Instruksional (TIK)}

Perumusan TIK menggunakan kaidah ABCD (Audience, Behaviour, Condition, Degree). TIK harus mengandung unsur-unsur yang dapat mengembangkan tes yang benar-benar dapat mengukur perilaku yang terdapat di dalamnya. (Suparman, 2014).

\section{Alat Penilaian Hasil Belajar}

Alat penilaian hasil belajar digunakan untuk mengukur keberhasilan perserta didik dalam menguasai kompetensi-kompetensi yang ada dalam TIK. Alat penilaian hasil belajar mungkin tidak perlu mengukur penguasaan peserta didik terhadap seluruh uraian pengajar dalam proses instruksional, karena apa yang diberikan pengajar belum tentu seluruhnya relevan dengan tujuan instruksional. Setiap alat penilaian hasil belajar yang relevan dengan TIK adalah valid untuk digunakan. Apabila di kemudian hari setelah proses instruksional seluruh peserta didik ternyata menguasai $80 \%$ perilaku dalam TIK tersebut, dapat ditafsirkan bahwa proses instruksional tersebut dianggap sudah efektif.

\section{Menyusun Strategi Instruksional}

Strategi instruksional adalah pendekatan dalam mengelola isi dan proses instruksional secara komprehensif untuk mencapai tujuan instruksional (Suparman, 2014). Strategi instruksional terdapat tiga komponen penting, yaitu:

a. Tujuan pembelajaran yang berisi kompetensi yang diharapkan dapat dicapai oleh peserta didik pada akhir pembelajaran.

b. Isi atau materi pembelajaran dengan urutan yang sesuai dengan urutan tujuan pembelajaran.

c. Pendekatan dalam mengelola pembelajaran yang melibatkan urutan kegiatan pembelajaran dan sistem pembelajaran yang merupakan pengintegrasian metode, media dan alat, serta alokasi waktu.

\section{Mengembangkan Bahan Instruksional}

Bahan instruksional yang dikembangkan dengan desain cover, desain sub bab, dan ornamen sebagai berikut: 

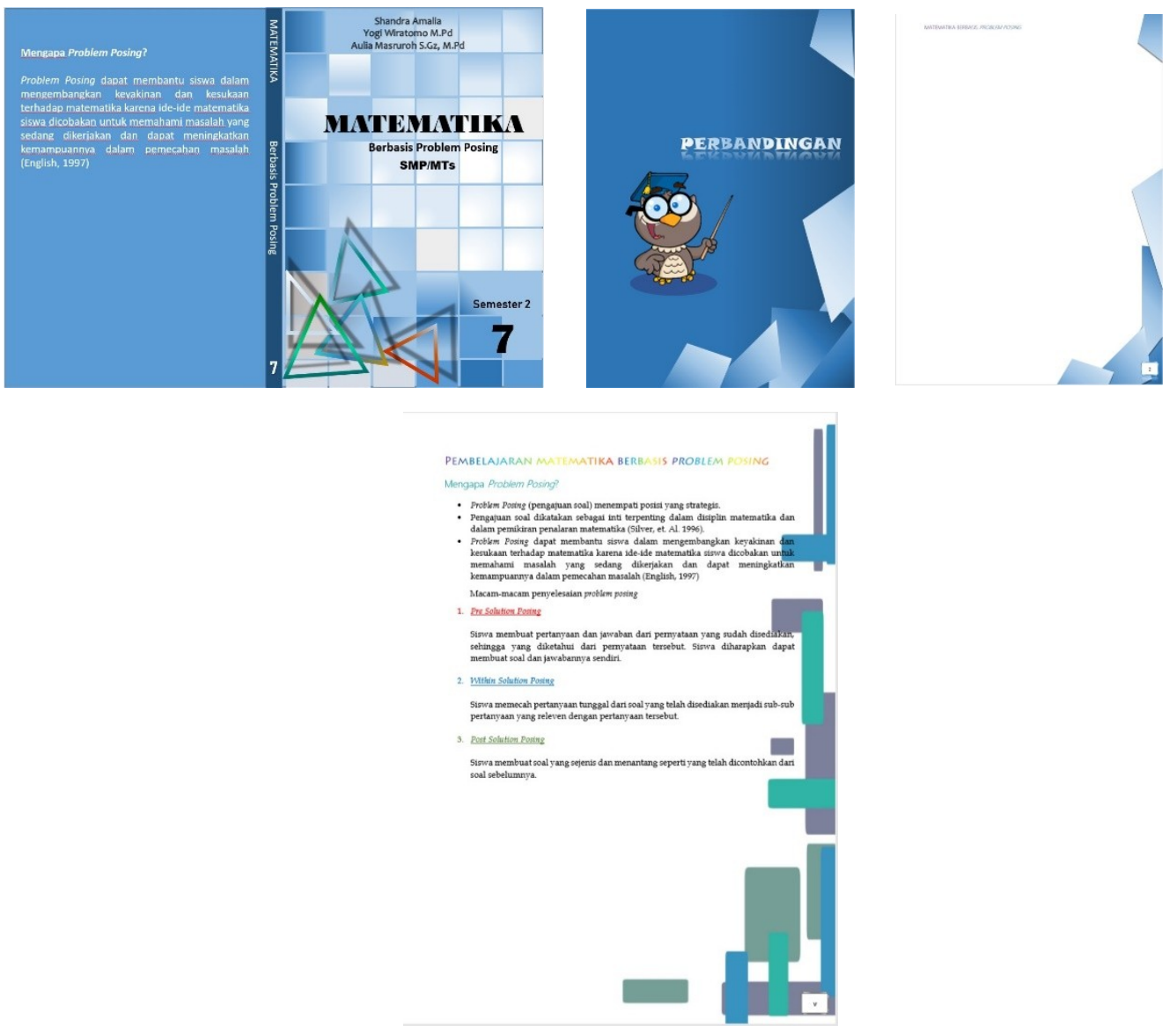

Gambar 3. Desain buku matematika berbasis problem posing.

Untuk memudahkan pengetahuan problem posing dalam pembelajaran, maka pada halaman awal dibuat pengertian dan konten problem posing.

Desain konten dibuat secara terstruktur dengan bagian pembuka terdiri dari peta konsep, kompetensi dasar dan tujuan pembelajaran. Pada bagian isi dibuat dengan langkah langkah pembelajaran yang memudahkan siswa, seperti dalam contoh soal narasi/cerita diberikan pewarnaan untuk memdefinisikan soal meliputi diketahui dan ditanyakan.

Langkah - langkah problem posing dalam tiap bab dibagi menjadi 3 cara yaitu pre solution posing, within posing dan post solution posting dengan tahapan - tahapan yang sistematis.

\section{Melakukan Evaluasi Formatif}

Evaluasi formatif bertujuan untuk menentukan apa yang harus ditingkatkan atau direvisi agar produk tersebut lebih sistematik, efektif, dan efisien. Proses pengembangan suatu produk instruksional, pelaksanaan evaluasi formatif adalah suatu keharusan dan berlangsung terus menerus.

Uji formatif yang dilakukan adalah dengan evaluasi tunggal pada tahap review oleh ahli di luar tim pendesain instruksional. Beberapa masukan yang diperoleh dari kelima narasumber berkenaan dengan evaluasi bahan instruksional 
dan proses desain instruksional, yakni sebagai berikut :

Tabel 2. Masukan Evaluasi Bahan Instruksional \& Proses Desain Instruksional

\begin{tabular}{|c|c|c|}
\hline No & Masukan Validator & Penguji \\
\hline 1. & $\begin{array}{l}\text { - Perhatikan kata ejaan dalam } \\
\text { kalimat } \\
\text { - Masih banyak terdapat kesalahan } \\
\text { berbahasa, khususnya dalam } \\
\text { penggunaan, tetapi harus direvisi } \\
\text { sesuai arahan yang sudah } \\
\text { diberikan. }\end{array}$ & $\begin{array}{l}\text { Yulian Dinihari, } \\
\text { M.Pd dan Nur } \\
\text { Indah Sari, M.Pd. } \\
\text { Tanggal } 10 \text { dan } 14 \\
\text { Agustus } 2019 .\end{array}$ \\
\hline 2. & $\begin{array}{l}\text { - Materi sudah sesuai dengan } \\
\text { silabus dan dapat digunakan } \\
\text { dalam pembelajaran. } \\
\text { - Diharapakan buku matematika } \\
\text { berbasis Problem Posing tidak di } \\
\text { kelas } 7 \text { saja. }\end{array}$ & $\begin{array}{l}\text { Arfatin Nurrahmah, } \\
\text { M.Pd dan Sri } \\
\text { Astuti, S.Pd } \\
\text { Tanggal } 10 \text { dan } 20 \\
\text { Agustus } 2019 .\end{array}$ \\
\hline 3. & $\begin{array}{l}\text { - Upayakan mulai halaman setiap } \\
\text { bab selalu ganjil } \\
\text { - Bagian pemisahan antar bab } \\
\text { dilatakkan tersendiri dan tidak } \\
\text { termasuk dalam halaman, serta } \\
\text { tidak ada isi apapun dibaliknya. } \\
\text { - Bagian cover belakang dijadikan } \\
\text { warna hitam saja. }\end{array}$ & $\begin{array}{l}\text { Leonard, M.M., } \\
\text { M.Pd dan Abdul } \\
\text { Karim, M.Pd } \\
\text { Tanggal } 19 \text { Agustus } \\
\text { 2019. }\end{array}$ \\
\hline
\end{tabular}

Dari beberapa masukan validator di atas dan dilakukan revisi produk untuk mendekati kepada kesesuaian buku dengan model pembelajaran problem posing. Bahan instruksional yang diadopsi dari Model Pengembangan Instruksional M. Atwi Suparman diharapkan mampu memfasilitasi pencapaian kompetensikompetensi peserta didik kelas 7 SMP dalam pemahaman materi matematika. Peserta didik dibiasakan untuk aktif dalam pembelajaran dan dalam memecahkan masalah sehari-hari. Pencapaian tujuan pembelajaran secara utuh tidak hanya mencakup transfer ilmu pengetahuan dari pendidik ke peserta didik, tetapi lebih ditekankan pada proses awal menyusun pembelajaran itu sendiri, dari mulai penentuan tujuan instruksional yang akan dicapai hingga pada aplikasi proses pembelajaran di dalam kelas.

Hasil dari pengembangan desain instruksional ini adalah produk berupa bahan ajar yang memuat materi SMP kelas 7. Bahan ajar ini dilengkapi dengan Tujuan Instruksional Umum (TIU), Tujuan Instruksional Khusus (TIK), indikator pencapaian kompetensi, peta konsep, latihan-latihan yang mengaplikasikan metode pembelajaran dari strategi pembelajaran kooperatif, serta dilengkapi dengan uji kemampuan dan latihan-latihan soal cerita dalam pengaplikasian materi dalam kehidupan sehari-hari untuk mengukur sejauh mana pemahaman materi dan kompetensi peserta didik.

\section{SIMPULAN}


Bahan ajar matematika SMP kelas VII untuk semester genap berbasis Problem Posing dalam desain instruksional yang dihasilkan ini telah dikembangkan dengan model pembelajaran intruksional M. Atwi Suparman, meliputi tahap pendahuluan, analisis, dan pengembangan prototype system, serta melaksanakan evaluasi formatif. Tahap pendahuluan terdiri dari mengindentifkasi kebutuhan instruksional dan menulis tujuan instruksional umum, melakukan analisis instruksional, serta mengindentifikasi perilaku dan karakteristik awal peserta didik. Tahap analisi dan pengembangan prototype system meliputi menulis tujuan instruksional khusus, menulis tes acuan patokan sebagai alat penilaian hasil belajar, menyusun strategi instruksional, serta mengembangkan bahan instruksional. Tahap evaluatif formatif yaitu dilakukannya perbaikan pembelajaran dengan dilandasi umpan balik hasil penelitian formatif. Evaluasi formatif yang dilakukan adalah dengan melakukan evaluasi tunggal pada uji pakar dengan menggunakan validasi dan revisi.

\section{DAFTAR RUJUKAN}

Fitriana, W. (2016). Analisis Kesalahan Buku Matematika pada Topik Segitiga dan Segiempat Kelas VII Semester II Serta Alternatif Pemecahannya. Prosiding Seminar Nasional Matematika IX, 147.

Haji, S. (2014). Pendekatan Problem Posing dalam Pembelajaran Matematika di Sekolah Dasar. UNIB Scholar Repository.

Hidayah, A. A., \& Leonard. (2013). Penggunaan Metode Problem Posing dalam proses Pembelajaran Matematika. Faktor, 1(1), 4. Retrieved from https://www.academia.edu/7558310/PENGGUNAAN_METODE_PROBLE M_POSING_DALAM_PROSES_PEMBELAJARAN_MATEMATIKA

Hobri. (2009). Model-Model Pembelajaran Inovatif. Jember: CSS.

Kurniasih, S. (2014). Strategi-Strategi Pembelajaran. Bandung: Alfabeta.

Prastowo, A. (2011). Metode Penelitian Kualitatif dalam Perspektif Rancangan Penelitian. Yogyakarta: Ar-Ruzz Media.

Sari, D.P. (2016). Analisis Kesalahan Buku Teks Matematika SMP/MTS Kelas VII Berdasarkan Objek Kajian Matematika. Seminar Nasional Matematika Dan Pendidikan Matematika, 78. Retrieved from Jurnal.fkip.uns.ac.id/index.php/snmpm

Setyosari, P. (2013). Metode Penelitian Pendidikan dan Pengembangan. Jakarta: Kencana Prenadamedia Group.

Sundayana, R. (2016). Kaitan antara Gaya Belajar, Kemandirian Belajar, dan Kemampuan Pemecahan Masalah Siswa SMP dalam Pelajaran Matematika. Masharafa, 5(2), 75.

Suparman, M. A. (2014). Desain Instruksional Modern: Panduan Para Pengajar \& Inovasi Pendidikan. Jakarta: Erlangga.

Tarigan, H. G. (2009). Pengkajian Pragmatik. Bandung: Angkasa.

Thobroni, M., \& Mustofa. (2012). Belajar dan Pembelajaran. Yogyakarta: ArRuzz Media. 